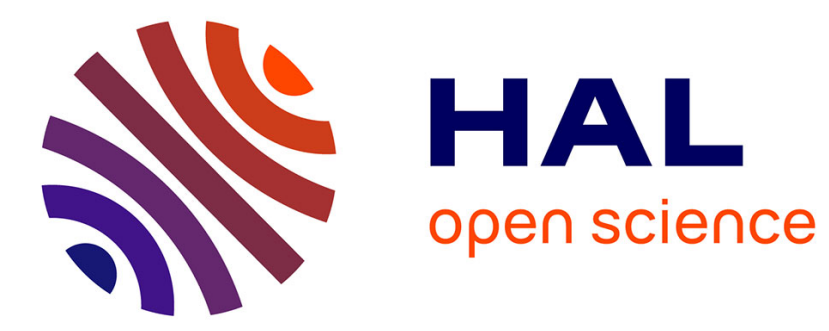

\title{
Subcontracting in Italian industry. Labour division, firm growth and the North-South divide
}

\author{
Anna Giunta, Annamaria Nifo, Domenico Scalera
}

\section{To cite this version:}

Anna Giunta, Annamaria Nifo, Domenico Scalera. Subcontracting in Italian industry. Labour division, firm growth and the North-South divide. Regional Studies, 2011, pp.1. 10.1080/00343404.2011.552492 . hal-00686086

\section{HAL Id: hal-00686086 https://hal.science/hal-00686086}

Submitted on 7 Apr 2012

HAL is a multi-disciplinary open access archive for the deposit and dissemination of scientific research documents, whether they are published or not. The documents may come from teaching and research institutions in France or abroad, or from public or private research centers.
L'archive ouverte pluridisciplinaire HAL, est destinée au dépôt et à la diffusion de documents scientifiques de niveau recherche, publiés ou non, émanant des établissements d'enseignement et de recherche français ou étrangers, des laboratoires publics ou privés. 


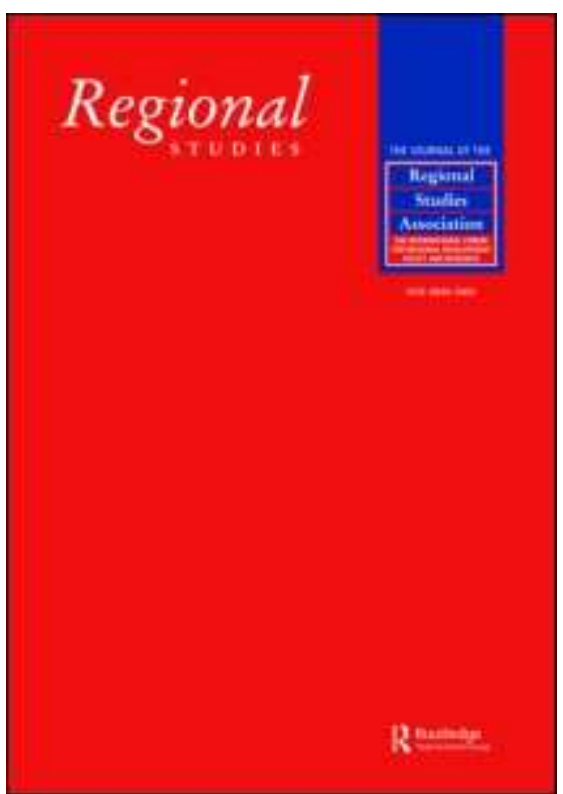

\section{Subcontracting in Italian industry. Labour division, firm growth and the North-South divide}

\begin{tabular}{|r|l|}
\hline Journal: & Regional Studies \\
\hline Manuscript ID: & CRES-2009-0013.R2 \\
\hline Manuscript Type: & Main Section \\
\hline JEL codes: & $\begin{array}{l}\text { D23 - Organizational Behavior|Transaction Costs|Property Rights < } \\
\text { Organization of Production < L2 - Firm Objectives, Organization, } \\
\text { and Behavior < L - Industrial Organization }\end{array}$ \\
\hline Keywords: & subcontracting, growth, location \\
\hline
\end{tabular}

\section{SCHOLARONE" \\ Manuscripts}




\section{Anna Giunta , Annamaria Nifo ${ }^{\star}$ and Domenico Scalera^}

Subcontracting in Italian industry. Labour division, firm growth and the North-South divide

- Department of Economics, Università degli Studi Roma Tre, Via Silvio D’Amico, 77, 00145 Rome, Italy. Email: agiunta@uniroma3.it

• Department PEMEIS, Università del Sannio, Piazzetta Arechi II, 82100 Benevento, Italy. Email: nifo@unisannio.it

^ Department PEMEIS, Università del Sannio, Piazzetta Arechi II, 82100 Benevento, Italy. Email: scalera@unisannio.it and Centro per la formazione in economia e politica dello sviluppo rurale, Via Università 96, 80055 Portici, Italy. 


\begin{abstract}
The aim of this paper is to investigate the impact of subcontracting on Italian manufacturing firms' growth in the second half of the 1990s. The main results are: i) producing as subcontractors does not penalize firms but can be a positive determinant of growth, especially when coupled with the propensity to innovate; ii) since a nonlinear relationship between growth and subcontracting emerges, an organizational mode not fully specialized in either subcontracting activity or direct sales may be optimal; iii) the deep dualism of the Italian industrial structure is confirmed, as Southern subcontractors show poorer performances and slower growth.
\end{abstract}

Keywords: Subcontracting, value chain, location, firm growth

JEL Codes: D23, L23 


\section{Introduction}

Since the 1990s, vertical disintegration in most industries and the globalization of intermediate goods' markets has led to significant changes in the pattern of international division of labour among manufacturing firms. These developments, combined with other factors (primarily increased competition from low cost producers and exchange rate constraints, preluding the introduction of a single currency) have had major consequences for the mature industrial systems in European countries, including Italy. The peculiar features of Italian industry (small average firm size, specialization in traditional industries, industrial districts, historical backwardness of firms in the South) added to the problems in the second half of the 1990s. This resulted in a serious productivity slowdown and significant reductions in export and market shares. This paper deals with the Italian manufacturing industry, with a particular focus on subcontracting firms, ${ }^{1}$ which represent a significant portion of Italy's manufacturing sector.

What are the effects of changes in the international division of labour on the performance and growth of subcontracting firms? How can subcontracting firms successfully enter the global value chain? The answers to these questions are far from straightforward. Our working hypothesis is that the reorganization of the division of labour may have induced a change in the "nature of subcontracting" in the most dynamic suppliers. Rather than being captive suppliers, acting in a monopsonistic context, the best subcontracting firms are urged to become agents in a trans-national productive network, and to engage in complementary rather than subordinate relationships with buyers. For these firms, globalization provides the chance to evolve, and progress from local to global suppliers. However, this evolution cannot be taken for granted. As scholars in the Global Value Chain (henceforth GVC) approach maintain, it is the position and the upgrading in (rather than simply participation in) the global value chain, pursued through innovation, that yield higher returns and better growth performance for subcontracting firms. This means that subcontractors involved in only the simplest traditional manufacturing activities remain the most exposed to the increased global competition. 
In this paper we investigate the relationship between the division of labour and firm growth in Italian manufacturing industry in the second half of the 1990s. The literature on firm growth is large, and dates back at least to Gibrat's law of proportionate growth (MANSFIELD, 1962). The novelty of our approach is its focus on organizational choice as one of the keys to growth. More specifically, in this paper we: a) try to understand whether and how subcontracting affects the growth dynamics of firms; b) test whether growth of subcontracting firms might be due to stronger incentives to innovate in order to move up the value chain, which would be consistent with the predictions of the GVC approach; and c) study the joint influence of subcontracting and location on growth by testing whether the growth dynamics of Southern subcontractors are significantly different from those of North and Centre subcontracting firms.

The paper is organized as follows. Section 2 discusses what determines globalization of the intermediate goods markets, the new pattern of international division of labour among industrial firms, and the difficulties experienced by Italian manufacturing firms to adapt to these changes. Section 3 describes possible interactions between positioning and upgrading along the GVC, the propensity for innovation, and firm growth. This section relies heavily on the suggestions of GVC scholars that the firm's position in the GVC, its innovative behaviour, and the GVC pattern of governance are crucial for determining firm growth performance. Section 4, which has three subsections, focuses on the empirical investigation. It presents the data and some descriptive statistics. The micro level data are from the Capitalia surveys of Italian manufacturing firms for 1995-1997 and 1998-2000, and provide information on a stratified sample of about 5,000 firms with at least 11 employees. The second subsection describes the estimation methods, and the third one presents the main results. The explanatory variables for growth considered in the econometric investigation, beside the commonly used regressors (age, size and past growth), include some organizational variables, such as subcontracting intensity and product innovation, proposed in the GVC approach. We include also a geographic variable, "localization", which is particularly relevant 
to the case of Italy, in order to detect possible differences in the growth of Southern and CentreNorthern firms. Section 5 presents the main conclusions and outlines some policy issues.

2. The globalization of intermediates markets and the (late) involvement of Italian manufacturing industry

During the last two decades profound changes in the international division of labour among firms have led to increasingly globalized intermediates markets. ${ }^{2}$ Outsourcing and offshoring ${ }^{3}$ of (stages of) production activities - mainly by (large) firms headquartered in developed countries - are major features of this evolution, for most industries resulting in the development of GVCs. ${ }^{4}$ The reasons for these changes are several and all have been widely investigated. First, the substantial reductions in trade barriers, tariffs and transportation costs have favoured market integration by reducing the costs of temporary exports/imports, thus including developing countries in international production networks as low cost producers of intermediate inputs. Second, the development and diffusion of Information and Communication Technologies (ICT) has fostered the spread of international outsourcing/subcontracting networks by: a) reducing the coordination costs among agents in the network and making geographic proximity less of a constraint; and b) making the different tasks and activities that constitute the production process separable in time and space (MILGROM and ROBERTS, 1990; NORDÅS, 2004, 2005). Third, the disintegration of multinational enterprises (MNE) (GEREFFI et al., 2005) means that subcontractors from different countries increasingly are included in these firms' international production networks, ${ }^{5}$ a process described by SALIOLA and ZANFEI (2009) as "the changing nature of multinational enterprises". ${ }^{6}$ Although the involvement of independent suppliers differs across sectors and countries and is highly dependent on their absorptive capacity, there is evidence that MNE outsourcing to independent local firms is growing (e.g. NORDÅS, 2005). MNEs' increasing recourse to local networks allows them greater bargaining power against national governments (IETTO-GILLES, 2002), better implementation of just-in-time production procedures (e.g. the automotive industry - STURGEON et al., 2008), and 
greater competitiveness through outsourcing to low cost suppliers (especially in emerging countries; see HUMPHREY and MEMEDOVIC, 2003). Finally, improvements in the quality of institutions induce more and more producers to trust inter-firm market relationships (ANTRAS and HELPMAN, 2008) even in the presence of uncertainty, incomplete contracts and potential opportunistic behaviours. Repeated collaborations, reputation and careful "selection of players" help to reduce hold-up costs and lock-in. Taken together, these factors make the spatial and functional reorganization of the division of labour even more valuable and offer more opportunities for larger profits for both outsourcer and subcontractor.

The globalization of intermediate inputs markets, stronger competitive pressure from Eastern European and Asian producers, exchange rate constraints prior to the introduction of the single European currency, and the development and spread of ICT, have provided powerful shocks for Italian manufacturing firms. These shocks led to productivity slowdowns and greatly reduced export and market shares in the second half of the 1990s. ${ }^{7}$

Lack of a prompt and adequate response from Italian industry to the challenges of globalization can be explained by its peculiarities. The traditional prevalence of small sized firms, became even more pronounced in the 1970s and 1980s. In those years a post-Fordist fragmentation of production combined with a rediscovery of the virtues of Marshallian industrial districts in North-East and Central Italy (BECATTINI, 1978, 1979) ${ }^{8}$ resulted in district firms becoming the most powerful drivers (MENGHINELLO, 2004) of Italian manufacturing industry performance. The competitive advantage of this organizational model was founded on: territorially bounded, deep division of labour among small and medium sized specialized firms; local specialization in a particular industry (especially "made in Italy" merchandise and mechanical engineering); low transaction costs based on high levels of trust and cooperation among agents; locally embedded practical and tacit knowledge; and pools of specialized labour.

Globalization is a major blow to this industrial district economy, and turns many traditional strengths into weaknesses. International low-cost competition renders specialization in traditional 
goods no longer sustainable, while the Maastricht constraints inhibit "competitive devaluation" of the Lira, the solution often resorted to in previous decades. The spread of ICT means codified and transmittable knowledge and information begin to supersede the tacit and informal knowledge in industrial district firms. Small size and low human capital endowments make adjustment to this new technological regime difficult for industrial district firms. ${ }^{9}$

These difficulties are worse for firms in Southern Italy. The South of the country is characterized by a historical lag of local manufacturing firms in terms of performance, productivity, market penetration and international openness. Several investigations (GIANNOLA and SCALERA, 1998; GUERRIERI and IAMMARINO, 2001) unambiguously confirm the persistence in the mid 1990s of a substantial gap between South and Centre-North of Italy industry. Southern manufacturing firms also are more vertically integrated due to higher transaction costs (GIUNTA and SCALERA, 2007) and thus are less able to profit from a reorganization of the domestic and international division of labour.

Nevertheless, eventually a share of Italian manufacturing firms manages to enter the GVC. Large firms, usually assemblers/buyers located in the downstream sections of the supply chains, progressively reduce their dependence on local suppliers by exploiting lower cost sources abroad, thus crowding out some Italian subcontractors. At the same time, some small and medium sized firms move from subcontracting to direct sales to final markets, or change from being local to becoming global suppliers (CAMUFFO et al., 2007). In order to face the mounting commercial pressure from low labour cost countries and to achieve better positions in the international value chain, firms abandon districts in search of lower costs, and engage in international outsourcing mainly in Central and Eastern Europe, the Balkans, the Mediterranean basin and South-East Asia.

General industry statistics do not capture the intensity of this phenomenon, but a number of case studies (e.g. TATTARA et al., 2006) and more systematic investigations (COSTA and FERRI, 2007; DAVERI and JONA-LASINIO, 2007; FALZONI and TAJOLI, 2008) have provided evidence of the increasing involvement of Italian firms in the GVC. However, this process affects 
the Mezzogiorno only marginally. ${ }^{10}$ According to UNIONCAMERE (2006), while quite a large number of firms (some 65\% in 2000) in the Northern, Central and Eastern regions of Italy make use of subcontractors outside the region and/or abroad, in Southern Italy the subcontracting network is organized mainly on a local basis, with about $65 \%$ of firms relying on provincial suppliers. From the point of view of subcontractors, this implies that suppliers located in the Mezzogiorno mostly serve a few customers in local markets, are in peripheral and weak positions in the value chain, and are involved in the least profitable stages of production. According to the few studies on this topic (e.g. CAMUFFO et al., 2007), Centre-North firms differ in that they exploit the chances offered by the international division of labour to reinforce their roles as specialized suppliers, while market globalization provides a strong incentive for greater openness to international markets and more innovative activity. Although they may not be industry leaders, these firms occupy more secure and more lucrative positions in the value chain. They frequently combine subcontracting activity with production for final markets, and perform the roles of both outsourcer and subcontractor. In Section 4 of this paper, we investigate whether these kinds of firms have productivity or growth gaps compared to non-subcontracting firms, or whether their participation and role in the GVC is enabling productivity and growth performance equal to or even greater than that of other firms.

3. GVC and firm growth: the role of product innovation

In a global scenario, as production processes are increasingly decomposed, commissioning firms abandon or reduce their positions at the core of manufacturing production to focus on more profitable activities (design, engineering, marketing). Consequently, the markets for intermediate goods get thicker, hold-up costs decrease, and suppliers are able to benefit from more intensive specialization (MCLAREN, 2000). The nature of subcontracting activities evolves, and more qualified and more specialized suppliers of intermediates emerge to serve not a single customer, but rather many final firms within a network of complementary relationships. Subcontracting firms are directly involved in more activities designed to offer differentiated, innovative products and 
services to a wider array of customers, and in becoming more autonomous in the global arena. They are faced with increasingly complex tasks, including the governance and policy of their own supply networks.

The theoretical and empirical literature discusses the features and effects of outsourcing and offshoring for firms' productivity, at some length ${ }^{11}$ (see, e.g., AMITI and WEI, 2006; OLSEN, 2006, GÖRG et al., 2008). However, the issue of the impact on firm performance of being a subcontracting firm has been rather overlooked. A few exceptions are KIMURA (2002) and RAZZOLINI and VANNONI (2009) which deal respectively with Japanese and Italian industrial firms. KIMURA (2002) concludes that subcontractors' profits are not higher than those of other firms, while RAZZOLINI and VANNONI (2009) find that the total factor productivity of subcontractors exporting to foreign markets is lower compared to direct exporters. In both studies, that particular organizational choice seems to be subject to a "subcontracting discount". Neither of these studies considers the link between the firm's organizational choice (i.e. being a subcontracting firm or selling directly to final markets) and the propensity to innovate, a link that may be crucial for at least two reasons. One concerns the impact of innovation on the rate of firm growth, based on the seminal contribution of MANSFIELD (1962), and widely empirically tested (GEROSKI et al., 1997, DEL MONTE and PAPAGNI, 2003; LOOF and HESHMATT, 2006, CORSINO and GABRIELE, 2010). The second reason is related to firms' participation in the global chain, which provides opportunities for the development of a set of innovative subcontractors. This aspect, which is a major issue of the GVC literature, was first analyzed by GEREFFI (1994) and then developed in a number of contributions, such as GEREFFI and KORZENIEWICZ (1994), KAPLINSKY (2000) ${ }^{12}$ HENDERSON et al. (2002) and HUMPHREY and SCHMITZ (2002).

According to the GVC approach, the positioning of a firm and its upgrading along the chain and the GVC pattern of governance, ${ }^{13}$ are crucial for determining growth performance. GEREFFI (1999) outlines a distinction between two types of production chains: a buyer driven commodity chain - common in labour intensive industries such as textiles and shoes, and a producer driven 
commodity chain - typical of industries such as automotive, electronics and civil aviation. In both these types of chains, the key players directly carry out the most innovation-intensive, highest return activities, both upward (design, engineering) and downward (marketing, retail). These activities yield high rents, while the simplest traditional manufacturing activities are the most exposed to the increasing global competition.

With regard to growth paths, the GVC approach identifies four, not mutually exclusive, paths of expansion for subcontracting firms:

a) increasing technical efficiency;

b) strengthening inter-firm connections with partners to build a more consistent and cooperative network than that of rivals;

c) improving the quality of their function along the chain, or moving to higher quality functions (e.g. from production to design);

d) introducing new products or increasing the range of products offered.

While a) and b) seem to be essential requirements for participation in the value chain, but do not warrant per se upgrading in the value chain or insure against the risk of future decline, strategies c) and d) are the keys to higher returns and growth. In relation to innovation, in particular, GEREFFI (1999) points out that the motivation for product innovation stems primarily from foreign buyers and global assemblers, the key GVC actors, which push subcontracting firms to satisfy their demand for more value added and more sophisticated products. Along these lines, several empirical studies (e.g. DOLAN and HUMPHREY, 2000; BAIR and GEREFFI, 2001; BAZAN and NAVASALEMAN, 2004; GIULIANI et al., 2005) find that integration in GVCs is a major stimulus to product innovation - especially for firms most able to meet foreign buyers' and global assemblers' demands.

In relation to the Italian experience, the GVC approach provides a rationale for the functional upgrading of many subcontracting firms located in the Northern and Central regions of Italy (see, e.g., AMIGHINI and RABELLOTTI, 2003 for the Veneto region, and CORÒ and 
GRANDINETTI, 1999 for the Marche region), or changes to the specialization of some industrial district firms from production of final commodities to the manufacture of machinery and equipment (DE ARCANGELIS and FERRI, 2005). HUMPHREY and SCHMITZ (2002) refer to this activity as inter-sectoral upgrading.

The major limitation of this line of analysis is that results are usually based on case study and/or anecdotal evidence, rather than on econometric investigation. This is probably because reliable data are scarce. The investigation in Section 4 is intended to overcome some of these limitations. Although our data do not allow us to test more broadly the ability of functional or intersectoral upgrading to explain subcontracting firms' growth, they do enable a focus on the role of product innovation as a determinant of firm growth in the GVC.

\section{The empirical investigation}

The empirical investigation has three main objectives. First, we study the relationship between subcontracting and firm growth (relative increases in sales or employees). Our working hypothesis is that subcontracting firms, when emancipated from their traditional inferior position with respect to customers, may perform comparably to or even better than other firms. This idea is consistent with the considerations discussed above and with empirical investigations that provide evidence of significant positive relationships between subcontracting and, respectively, survival rates (MAZZOLA and BRUNI, 2000), financial ratios (ROE - Return on Equity, and ROI - Return on Investment), (INNOCENTI, 2003) and input productivity and returns (GIUNTA and SCALERA, 2007, for Central and Northern Italy firms). ${ }^{14}$ Second, we test whether growth among subcontracting firms is based on the ability to innovate and upgrade in the GVC, which would be consistent with the predictions of the GVC approach. Third, we evaluate possible geographic differences in the relationship between subcontracting and growth.

We also test for the relevance of the neutrality result or "Gibrat's law of proportionate growth". According to Gibrat's law, firm growth rate is stochastic and, therefore, independent of 
size, uncorrelated to past growth, and not linked to other explanatory variables. There is a large theoretical and empirical literature on Gibrat's law, dating back to MANSFIELD (1962). The most relevant criticism comes from models of firm learning inspired by the seminal work of JOVANOVIC (1982), showing a negative relationship between the rate of firm growth, and age. Other contributions, such as SUTTON (1997) and HART (2000), refute the hypothesis of no serial correlation in growth rates by showing the strong persistence of growth. Several other empirical studies (e.g. EVANS, 1987a and 1987b for the US, and DUNNE and HUGHES, 1994 and VARIYAM and KRAYBILL, 1992 for the UK) show that there is a clear inverse relationship between growth rate and size, and/or age, in manufacturing and services firms. These results are confirmed substantially by AUDRETSCH et al. $(1997$; 1999) for Dutch firms operating in different industrial sectors, and wholesale trade, by HARHOFF et al. (1998) for a sample of German firms, by MACPHERSON (1996) for South Africa, and by YASUDA (2005) who shows the existence of a strong negative correlation between growth rate and age or initial size for a sample of 14,000 Japanese manufacturing firms.

\subsection{The data}

Before proceeding to the econometric analysis, we highlight some features of our data and provide a short descriptive analysis of the growth performance of our sample firms. Our investigation uses a unique dataset based on the $7^{\text {th }}$ and $8^{\text {th }}$ waves of the Capitalia "Survey on manufacturing firms", which is carried out every three years. ${ }^{15}$ Capitalia collects data on a large number of variables from a stratified representative sample of around 5,000 Italian manufacturing firms with at least 11 employees. The $7^{\text {th }}$ wave, covering the period $1995-1997$, has 4,497 observations; the $8^{\text {th }}$ wave (1998-2000) has 4,680 observations; 1,299 firms are sampled in both waves. The sample includes the whole population of large firms (at least 500 employees), while for the 11-499 employees class, the firms included in the sample, in terms of employment, represent about $12 \%$ of the population. The detailed questionnaire that is administered to all the firms asks about the values of a large 
number of organizational, structural and performance variables for the current year and, in some cases, for the previous one or two years. For example, there is a question about subcontracting intensity in the current year. Also, each firm surveyed is asked to provide a 10 year time series for a selected number of balance sheet variables. Capitalia does not release information about nonresponding firms.

The A panels in Tables 1 and 2 show the firm size distributions for classes of employees and real sales (billion Liras at year 2000 values); the B panels record annual average growth rates for employees and real sales for 1995-1997 and 1998-2000. Both tables provide separate information for:

a) Centre-North, and Mezzogiorno firms;

b) non-subcontractors (NOSUB, firms producing exclusively for direct sale); weak subcontractors (LOSUB, i.e. up to $50 \%$ of total sales due to subcontracting); strong subcontractors (HISUB, i.e. more than $50 \%$ of total sales due to subcontracting); and absolute subcontractors (ONSUB, i.e. firms producing only as subcontractors);

c) five size classes (i.e. according to the conventional European standard classification, 11-50, 51100, 101-250, 251-500 and over 500 employees).

[Table 1 here]

[Table 2 here]

Our sample reflects the population size distribution of Italian manufacturing firms and includes a large number of small firms. Table 1 panel A shows that over $70 \%$ of firms employ up to 50 workers, but only $8.6 \%$ have more than 250 employees. In terms of annual sales (Table 2, panel A), $56 \%$ of the sample have revenues of less than 10 billion Lira (around $€ 5.16$ million) and $88 \%$ have revenues of less than 50 billion Lira ( $€ 25.8$ million). The majority of firms (about $86 \%$ ) in the sample are in the Central and Northern regions of Italy with medium-large firms (more than 250 employees) making up $9.2 \%$ of the sample in the Centre-North and $4.6 \%$ in Southern Italy. The smallest firms (less than 50 employees) are more often subcontractors: $41.4 \%$ are exclusive 
subcontractors, while $39.2 \%$ never do subcontracting work. The corresponding shares for other firms are $24.9 \%$ (exclusive subcontractors) and 55.5\% (non-subcontractors).

The B panels show that, with one exception, the sampled firms are characterized by positive (and in some cases fairly high) average growth rates. At this stage, there does not seem to be a clear relationship between growth rate and firm size. In terms of geographic differences, with the exception of non-subcontractors (NOSUB) and weak subcontractors (LOSUB), Centre-North firms show higher rates of growth for employees and sales. If we focus in more detail on the relationship between subcontracting intensity and growth, the evidence is mixed. In brief, the groups of exclusive subcontractors (ONSUB) and strong subcontractors (HISUB) show the highest growth rates in real sales while the other two groups show on average higher employment growth. Of more interest is that, in almost all cases, each of the middle groups (LOSUB and HISUB) show higher rates of growth of sales and employees than the extreme groups (i.e. LOSUB grow more than NOSUB and HISUB more than ONSUB). This suggests a non-monotonic (i.e. increasing and then decreasing) relationship between growth rate and subcontracting intensity. The rows in Tables 1 and 2 show that this pattern applies to all firm sizes and to the overall group of Centre-North firms. Instead, in Southern firms growth rates tend to decrease with subcontracting intensity. ${ }^{16}$ This result is confirmed by the econometric analysis; interpretations are provided in Section 4.3.

To assess the statistical significance of differences among groups, we performed ANOVA tests (Table 3) on the differences, which in most cases are statistically significant.

[Table 3 here]

\subsection{The estimation method}

We estimate the following three equations for growth in real sales and employees.

$$
\begin{aligned}
& \Delta y_{i t}=\alpha+\theta_{1} y_{i t-1}+\theta_{2} \Delta y_{i t-1}+\theta_{3} A G E_{i t}+\gamma_{1} S O U_{i t}+\gamma_{2} S U B_{i t}+\beta_{1} A V K_{i t}+\beta_{2} I C T_{i t}+\beta_{3} I N P_{i t}+u_{i t} \\
& \Delta y_{i t}=\alpha+\theta_{1} y_{i t-1}+\theta_{2} \Delta y_{i t-1}+\theta_{3} A G E_{i t}+\gamma_{1} S O U_{i t}+\gamma_{2} S U B_{i t}+\beta_{1} A V K_{i t}+\beta_{2} I C T_{i t}+\beta_{3} I N P_{i t}+ \\
& +\beta_{4} I X S_{i t}+u_{i t}
\end{aligned}
$$


and

$$
\begin{aligned}
\Delta y_{i t}=\alpha & +\theta_{1} y_{i t-1}+\theta_{2} \Delta y_{i t-1}+\theta_{3} A G E_{i t}+\gamma_{1} S O U_{i t}+\gamma_{2} S U B_{i t}+\gamma_{3} S U B_{i t}{ }^{2}+\gamma_{4} S X S_{i t}+\gamma_{5} S X S_{i t}{ }^{2}+ \\
& +\beta_{1} A V K_{i t}+\beta_{2} I C T_{i t}+\beta_{3} I N P_{i t}+u_{i t}
\end{aligned}
$$

where $i$ is the firm, $t=1,2$ the 1998 or 2001 survey, $y_{i t}$ is the $\log$ of real sales SAL or the $\log$ of number of employees EMP; AGE is the log of firm age (years); SOU is a dummy taking the value 1 if the firm is localized in the Southern region; SUB is subcontracting intensity; and AVK (the ratio of added value over capital) is a typical indicator of productivity. ICT and INP are two dummies used as proxies for attitude to innovation; they take the value 1 if during the last three years the firm has respectively invested in ICT and introduced a product innovation. The definition of these variables and the main descriptive statistics are reported in Table 4. Finally, $\Delta y_{i t}$ is the first difference $y_{i t}-y_{i t-1}$. Significance of parameter $\theta_{l}$ would indicate dependence of growth rates on the initial value $y_{i t-1}$, while significance of $\theta_{2}$ would imply growth persistence. According to Gibrat's law, neither of these parameters should be significantly different from zero.

[Table 4 here]

The interaction terms IXS and SXS respectively are the products of INP and SUB and SOU and SUB. IXS is introduced to assess the impact of innovation on the sensitivity of growth to subcontracting intensity. As we pointed out above, within the set of subcontractors, the GVC approach distinguishes a group of innovative firms able to upgrade along the value chain and to grow more than other firms. This means that the subcontracting firm should benefit substantially from innovation since it enables a better position in the value chain. Thus, the expected sign of the IXS parameter $\beta_{4}$ is positive. Specification (2) allows us to make separate evaluations of the marginal effect of innovation on growth, for non-subcontractors (the parameter $\beta_{3}$ ) and for absolute subcontractors (the sum $\beta_{3}+\beta_{4}$ ).

The product SXS and the squared term in equation (3) test the hypotheses that the relationship between subcontracting intensity and firm growth is: a) structurally different for the 
South and the Centre-North; and b) non-linear. From (3), we can show that the marginal effect of subcontracting on growth rate is $\gamma_{2}+2 \gamma_{3} S U B$ for Centre-North and $\gamma_{2}+\gamma_{4}+2\left(\gamma_{3}+\gamma_{5}\right) S U B$ for Mezzogiorno. This means we can test the hypothesis of geographical structural differences in the relationship between subcontracting and growth by checking the statistical significance of $\gamma_{4}$ and $\gamma_{5}$, which, in turn, correspond to the differences $\left(\gamma_{2}^{S}-\gamma_{2}^{C N}\right)$ and $\left(\gamma_{3}^{S}-\gamma_{3}^{C N}\right)$, where $S$ and $C N$ respectively denote the parameters of the regressions on the sub-samples relative to Southern and Centre-North firms. We test for non-linearity by considering the statistical significance of $\gamma_{3}$ and $\gamma_{5}$. Finally, in equation (3), the marginal effect of localization (i.e. the difference in average growth between South and Centre-North) is equal to $\gamma_{1}+\gamma_{4} S U B+2 \gamma_{5} S U B^{2}$. Using specification (3), we can run regressions on the whole sample, without the need for separate estimates for the two subsamples.

Concerning the estimation method, our choices are strongly constrained by the nature of the available data. In particular, since firms are asked to indicate the value of subcontracting intensity for one year only, our data seem more suited to pool than to panel treatment, for at least two reasons. First, the number of firms sampled in both waves of the survey is just slightly more than $25 \%$ of cases, which would make a panel strongly unbalanced with a minor informational advantage with respect to pooled data, or alternatively would exclude many observations (almost all Southern firms). Second, and more important, a panel would not allow (at least in a fixed effects specification) the use of the time invariant dummy variable SOU, which is crucial for our analysis.

Also, we consider the possibility of reverse causation, i.e. that organizational mode might be influenced by growth prospects. In this case, the variable SUB would be affected by endogeneity, thus making OLS (ordinary least squares) estimates biased and inconsistent. Therefore, as well as OLS, we run instrumental variables regressions (GIV) following a two stage procedure. In the first stage, we regress SUB on the instruments included among the right hand side variables in equations (1), (2), and (3), plus some excluded instruments. In the second stage, we substitute the fitted values for SUB from the first stage regression and estimate (1), (2) and (3). The unavailability of lagged 
data on subcontracting introduces the problem that we have to choose the excluded instruments from the other variables surveyed by Capitalia. The diagnostics on exogeneity and relevance of instruments allow us to select the three variables ROI, AVL (the ratio between added value and employed) and HUM (an indicator of human capital measured by the share of workers with secondary schooling) as appropriate excluded instruments. ${ }^{17}$

\subsection{The results}

Tables 5 and 6 present the results of the OLS and GIV estimations of equations (1), (2) and (3), respectively for rates of growth in real sales and employees. Our first finding is related to the dependence of growth rates on the initial values of real sales and employment. In all cases, growth rates are negatively related to the initial value with a significance level not lower than $5 \%$. Theoretical growth rates are considerable for the lowest size (growth rate of employment is higher than $30 \%$ for firms with 11 employees), but much lower as firm size increases (17\% for 31 employees, $9 \%$ for 51 employees and $4 \%$ for 100 employees). Estimates of parameter $\theta_{2}$ indicate negative statistically significant growth persistence for employees (not for real sales), which is in line with the literature on Italy (CONTINI and REVELLI, 1989). The overall conclusion is that the results of Tables 5 and 6 support the findings in most of literature, of empirical lack of validity for Gibrat's law.

[Table 5 here]

[Table 6 here]

In almost all cases, the control variables AGE, AVK, ICT and INP show a relationship with growth rates that is consistent with the theoretical predictions. In particular, the regressions confirm that firm age negatively affects the propensity to grow (but the link is statistically significant only for sales), while, in most cases, capital productivity, attitude to innovation and propensity to invest in ICT have a positive impact on growth rates. The latter results, although theoretically not 
surprising, are important since they contradict some of the findings in the literature (e.g. DEL MONTE and PAPAGNI, 2003; OLIVEIRA and FORTUNATO, 2006).

Moving on to the results connected more closely with subcontracting, we notice that in the estimation of equation (1) neither subcontracting intensity nor geographic location have a statistically significant effect on firm growth. In equation (2) the estimated parameters of the control variables are mostly unaltered, with the exception of age, which loses significance in three out of four cases. More important is that the introduction of the interaction factor IXS between innovation (INP) and subcontracting intensity (SUB), confirms that, on the one hand, innovation is crucial for growth for subcontractors, and on the other hand, an increase in subcontracting intensity leads to higher growth in innovating firms. These results are obtained simply by noting that the estimated coefficient of the variable IXS $\beta_{4}$ is positive and statistically significant (slightly above $5 \%$ for employee growth), while $\beta_{3}$ and $\gamma_{2}$ are not significantly different from zero. Estimation of equation (2) shows that it is innovative subcontracting (rather than just subcontracting activity) that is positively related to growth, which is consistent with the view that product innovation and good positioning in the value chain are linked to growth.

In the non-linear specification (3), the effect of subcontracting on growth is definitely greater. In this case, the parameters of the control variables are substantially unaltered but the estimates of the $\gamma$ parameters become statistically significant. In addition, the results show that there is strong geographic differentiation. The estimation of equation (3) suggests that location in the South negatively affects firms' growth performance. Moreover, the relationship between subcontracting and growth varies over the geographic areas considered. In the case of Centre-North, the relation shows a reversed U-shape with the highest value around $51 \%$ of subcontracting intensity for both employees and real sales. The marginal effect at the average value for subcontracting is always positive, between 0.22 and 0.31 for sales growth (1\% increase in subcontracting intensity provides about $0.25 \%$ increase in growth of real sales) and between 0.02 and 1.35 for the growth in employment. The theoretical forecast of sales growth varies from $-4 \%$ for 
non subcontractors, $+18 \%$ for firms with subcontracting intensity equal to 0.51 , and $+3 \%$ for absolute subcontractors. For employment growth, the theoretical forecast varies from $-9 \%$ for nonsubcontractors and absolute subcontractors to $+33 \%$ for intermediate subcontractors. The reverse Ushaped relation does not hold for the Mezzogiorno, where the impact of subcontracting is always negative at any value for subcontracting. At average subcontracting intensity, the marginal effect is between -0.18 and -0.57 for sales growth, and between -0.09 and -0.14 for employee growth. The theoretical forecasts of growth of both sales and employment are between $+8 \%$ for nonsubcontracting firms and $+1 \%$ for absolute subcontractors.

To summarize, the estimation of equation (3) seems to confirm the indications from equation (2). In the advanced areas of Italy, producing as subcontractors does not penalize firms but is a rather successful organizational choice and a crucial positive determinant of growth. However, this result does not hold for Southern firms, most likely because the nature of subcontracting in that area is still relatively underdeveloped and the firms involved in these activities are less productive.

As a robustness check, we estimated equations (1), (2) and (3) using alternative proxies for firm productivity, returns and attitude to innovation. Compared to the results presented in Tables 5 and 6, these changes produce only minor effects on the coefficient estimates, and on the signs and intensity of the relationships between growth and subcontracting.

Thus, our econometric investigation allows us to draw the following main conclusions. First, in accordance with most of the literature, Gibrat's law is rejected, as current growth rate does not seem to be independent of variables such as age, initial size and past growth rates. Second, subcontracting intensity turns out to be a determinant of growth when coupled with the propensity to innovate: within the subsample of subcontracting firms, we can confirm that innovative firms grow faster. This finding seems to be consistent with the GVC view on the crucial nexus between product innovation, upgrading along the value chain, and firm growth. Third, the non-linear relationship identified between subcontracting and growth in the Centre-North regions highlights that an organizational mode not fully specialized in either subcontracting activity or direct sales 
may be optimal. This means that subcontracting cannot be considered a marginal choice for less productive firms to access the market, but rather should be seen as an avenue to growth. Finally, for Southern firms the relationship between subcontracting and growth is peculiarly monotonically decreasing, which hints at the possibly different nature of subcontracting in this area, which retains traditional traits and is therefore negatively related to growth.

\section{Concluding remarks and policy issues}

The global disintegration of production and the expansion of the GVC with its peculiar nature of "trade in tasks" (GROSSMAN and ROSSI-HANSBERG, 2006) have attracted much scholarly attention in recent years.

However, while there are a large number of studies on outsourcing, i.e. the optimal allocation of firm's sourcing across different sites, little attention has been paid to subcontracting, i.e. to firms producing for outsourcers and, thus, being complementary to international production sharing in global networks. Some evidence on subcontracting choice and performance is provided by authors inspired by the GVC approach proposed by GEREFFI and KORZENIEWICZ (1994), which considers the positioning of a firm and its upgrading along the GVC.

This paper contributes to this stream of literature by focusing on subcontracting to explain firm growth in Italy in the second half of the 1990s, following changes in the pattern of the international division of labour and the development of GVCs. The peculiar features of Italian manufacturing industry, i.e. small average size of firms, large proportion of subcontracting firms in total firms, the industrial district model characterizing the Centre-North regions, the historical backwardness of firms in the South, make Italy particularly suitable for an investigation of industrial firm subcontracting. We exploited a detailed micro-level data set that enabled econometric investigation of a representative sample of almost 5,000 Italian manufacturing firms, between 1995-2000. Estimating regression equations marks a significant difference from most contributions to the GVC stream of research, which is mainly based on case studies and descriptive 
analysis.

Our underlying research hypothesis is that the "nature of subcontracting" changed over the time span considered. In the presence of firm heterogeneity, the development of GVCs allowed the best subcontractors to achieve better performance, higher profits and growth. They took the risks, bore the sunk costs, took on more responsibilities in the GVCs, undertook more complex tasks than in the past, and accordingly can enjoy the advantages accruing from international production fragmentation.

Our specific aim in this paper was to understand whether and how the choice to be a subcontractor affects firm growth. We tested whether subcontracting firms' growth could be due to greater incentives to innovate for a subset of subcontracting firms keen to move up the value chain, in line with the predictions of the GVC approach. Moreover, we studied the joint influence of subcontracting and location on growth, by testing whether in Italy the growth pattern among Southern subcontractors is significantly different from that experienced by North and Centre subcontracting firms.

The central and novel conclusions of this paper are several. First, in the current scenario of global fragmentation of production, subcontracting cannot be considered just to be a marginal and residual choice of ex ante less productive firms, but should be seen as a growth strategy; second, subcontracting, when coupled with the propensity to innovate, turns out be a determinant of firm growth. This finding provides econometric support to the GVC view of the importance of the nexus between product innovation, upgrading along the value chain, and firm growth. Third, we find that the current pattern of international division of labour exacerbates the dualism in the Italian industrial structure. The relationship between subcontracting and growth of Southern firms is peculiarly monotonically decreasing, which suggests the possibly different "nature" of subcontracting in the South, which has retained its traditional traits and, therefore, is negatively related to growth. As Southern subcontractors grow less than final producers and less than Centre- 
North subcontractors, they seem doomed to be increasingly exposed to the risk of being crowded out and being the losers in the competition with subcontracting firms from the emerging countries.

The findings in this paper have some implications for policy. OECD (2007b) has stated that the globalization of value chains poses major policy challenges to the OECD countries, as well as new opportunities. The findings in this paper support these claims and underline the importance of policy interventions to address the backwardness of Southern firms in Italy.

Two requirements seem to be essential and interdependent to allow subcontracting firms to move up the value chain: penetrating foreign markets and sustaining a process of continuous innovation. In terms of the former requirement, several studies (IACOVONE and JAVORCIK, 2010; KOENIG et al., 2010) point out that, among other factors, uncertainty and information asymmetries about export markets are serious obstacles for small and medium sized enterprises. Operating in a globally competitive market may, however, force firms to become more engaged in innovation activities. As we argue in the paper, this pressure may arise from coming in relation with large and multinational firms. The latter, acting as foreign buyers and global assemblers in the GVCs, provide strong incentives for product innovation.

Both requirements point to the need for public intervention. Public policy aimed at facilitating the flow of export-specific information and supporting the diffusion of knowledge on export markets may have a positive impact on export performance - KOENIG et al. (2010) document the case of French firms. A complementary policy would be to provide financial or fiscal incentives for small and medium sized firms to cooperate - for example, through consortia - which would allow achievement of the critical mass needed to bear the sunk costs of foreign market penetration. At the same time, policies to attract foreign direct investment would be profitable in the light of the role played by multinationals in GVCs.

With regard to Southern subcontracting firms, it is not an overstatement to say that, since the late 1990s, there has been no coherent, stable, and sound regional policy for the South of Italy. As many studies show (ROSSI, 2005; CANNARI et al., 2009; GIUNTA, 2010; SCALERA and 
ZAZZARO, 2010) the New Regional Policy, introduced at the end of the 1990s, has proven disappointing in terms of results. Policies to attract foreign investment have been subject to frequent "stop and go" and to inefficient performance of the institutional actors. Moreover, inefficient policy making has resulted in the failure for the policy designed to encourage the setting of consortia to sustain foreign market penetration of small and medium sized enterprises. Such a policy has not been sufficiently rigorous due to poor ex ante evaluation of financed projects, which has enabled opportunistic behaviour in the form of coalitions of entrepreneurs establishing consortia in order to acquire public money but without any intention or capacity to generate those collective goods - for instance, a common export trademark, outlets for foreign fairs and so on - which were the real targets of public intervention.

While the failure of New Regional Policy may provide grounds for the complaints of those who claim that regional policies do not work, the firm level evidence in this paper shows that globalization is likely to deepen the divide between the Centre-North and the South of Italy. This calls for a policy debate on how to complement necessary (and probably no longer sufficient) policies to improve the functioning of labour and product markets with efficient policies to support firms in less advantaged areas to move up the value chain. 
Notes

${ }^{1}$ Subcontracting firms are firms that sign contracts with client firms to supply intermediate products (specific components and services or more complex inputs). In what follows, the term "subcontracting intensity" is used to refer to the share of sales related to subcontracting over total sales.

${ }^{2}$ Several studies provide evidence of this phenomenon, e.g. OECD (2007a); MARIN (2006); HAVIK and MCMORROW (2006). In particular, HAVIK and MCMORROW (2006) estimate that between 1992 and 2000 the world average share of intermediate imports in total imports rose by some 4 percentage points, with increases of 6 percentage points for Europe, 3 for USA, 5 for South East Asia and 9 for China. JONES and KIERZKOWSKI (1990) wrote a seminal piece on the emergence of a new trend in globalization, based on advances in the technologies of transportation and communication and the decomposition of the production process across borders.

${ }^{3}$ There are no clear cut definitions in the literature of outsourcing and offshoring (and their relative measures); see OECD (2007a). In the present paper, outsourcing and offshoring mean respectively the relocation of activities outside the firm to an independent input supplier (subcontractor) and the relocation of activities to a different country within a structure belonging to or external to the firm.

${ }^{4}$ The value chain is the set of activities involved in the production and sale of commodities. It is global when activities are allocated across firms localized in several different countries. For a survey of industrial subcontracting networks, see SACCHETTI and SUGDEN (2003).

${ }^{5}$ However, a substantial part of international vertical specialization among MNEs also takes place through these firms' intra-industry trade in intermediate inputs (BORGA and ZEILE, 2004). See also ANTRAS (2003) which underlines that capital-intensive intermediate goods tend to be imported within the boundaries of multinational firms, and HANSON et al. (2003) which documents equally impressive growth in trade in MNEs.

${ }^{6}$ Worthwhile to mention here is the eclectic paradigm of international production proposed in DUNNING (1993). For a more recent appraisal of OLI (Ownership, Location, International 
Advantage) theory in light of the changing characteristics of MNEs activity and the global economic scenario, see DUNNING (2001). The impact of MNEs investments on local subcontracting networks has been documented, e.g. by DRIES and SWINNEN (2004).

${ }^{7}$ From 1994 to 2005, annual labour productivity growth was $0.5 \%$ on average. In the same period, the share of Italian exports on total world exports decreased from 4.5\% to 2.9\%; see ROSSI (2006). ${ }^{8}$ A comprehensive analysis of industrial districts is provided by BECATTINI et al. (2009). On the geography of Italian industrial districts, see SFORZI (2002).

${ }^{9}$ Several authors argue that the gains in productivity associated with ICT investment are conditional on the micro-complementarities among ICT adoption, internal reorganization processes and high levels of human capital (see BRYNJOLFSSON and HITT, 2000; BRESNAHAN et al., 2002; FALK, 2002; HUR et al., 2005 and, with specific reference to Italy, TRENTO and WARGLIEN, 2003, BUGAMELLI and PAGANO, 2004, LUCCHETTI and STERLACCHINI, 2004).

${ }^{10}$ Mezzogiorno is the term used to denote the South of the country; in the literature it refers to the mainland regions of Abruzzo, Molise, Campania, Basilicata, Apulia and Calabria plus the islands of Sicily and Sardinia.

${ }^{11}$ Other possible effects of outsourcing have also been investigated. E.g. there has been intense discussion of the impact on wages and employment; see HEGGER and KREICKEMEIER (2008) and KOHLER (2009).

${ }^{12}$ GEREFFI and KORZENIEWICZ (1994) use the term "global commodity chain", rather than GVC. The word "commodity" implies the production of undifferentiated products in processes with low barriers to entry, whereas, according to KAPLINSKY (2000: p. 9), "the search for sustainable income growth requires producers to position themselves precisely in non-commodity, high barriers to entry activities in the value chain”. HUMPHREY and SCHMITZ (2002) report that Gereffi and other researchers, at a workshop held in Bellagio (Italy) in September 2000, agreed to use the term GVC to refer to firms' linkages in global chains. 
${ }^{13}$ HUMPHREY and SCHMITZ (2002) suggest that four types of value chain relationships can be distinguished: arm's length relations; networks; quasi hierarchies; hierarchies. Among others, GIULIANI et al. (2005) deal with the relationship between value chain governance and firm upgrading.

14 Note, however, that some studies (e.g. GEROSKI, 1998) find poor correlation between performance indicators based on accounting measures and growth rates.

${ }^{15}$ The statistics in Tables 1 to 4 are calculated from CAPITALIA $(1998 ; 2001)$ data; Tables 5 and 6 present the results of the econometric estimations carried out using data from the same sources. Where necessary, data are deflated by the ISTAT price index NIC.

${ }^{16}$ The same conclusions hold if we consider median growth rates (in parentheses in Tables 1 and 2). Especially for employment growth (Table 1), median values are considerably lower than mean values, indicating that high average growth rates are presumably due to a relatively small number of firms growing very quickly.

${ }^{17}$ The Sargan tests reported in Tables 5 and 6 do not reject the hypothesis that over-identification constraints hold. Secondly, the F test on the joint significance of excluded instruments in the first stage regression always rejects the null hypothesis of joint insignificance, even though in two out of six cases - equations (2) and (3) for growth of real sales - the F statistic does not reach the Stock and Yogo (2005) strong instrument critical value. 
Acknowledgements

We gratefully thank two anonymous referees, Alessandro Arrighetti, Marco Corsino, Christopher Gilbert, Maria Luisa Segnana and Paola Villa for their comments on a previous version of this paper; Area Studi Capitalia for providing access to their database; Cynthia Little and Eleonora Pierucci for research assistance. 


\section{References}

AMIGHINI A. and RABELLOTTI R. (2003) The effect of globalisation on industrial districts in Italy: evidence from the footwear sector, Working Paper 64, SEMEQ Department, University of Eastern Piedmont.

AMITI, M. and WEI S. J. (2006) Service offshoring and productivity: evidence from the United States, NBER Working Paper 11926.

ANTRAS P. (2003) Firms, contracts, and trade structure, The Quarterly Journal of Economics 118, $1375-418$.

ANTRAS P. and HELPMAN E. (2008) Contractual frictions and global sourcing, in HELPMAN E., MARIN D. and VERDIER T. (Eds) The organization of firms in a global economy, pp. 9-54. Harvard University Press.

AUDRETSCH D. B., KLOMP L. and THURIK A. R. (1997) Do services differ from manufacturing? The post-entry performance of firms in Dutch services, Discussion Paper, No. 1718, Centre for Economic Policy Research.

AUDRETSCH D. B., KLOMP L. and THURIK A. R. (1999) Innovation, industry evolution and employment, Nordic Labour Market Research on Register Data, 230-252. Cambridge University Press.

BAIR J. and GEREFFI G. (2001) Local clusters in global chains: The causes and consequences of export dynamism in Torreon's blue jeans industry, World Development 29,1885-903.

BAZAN L. and NAVAS-ALEMAN L. (2004) The underground revolution in the Sinos Valley: A comparison of upgrading in global and national value chain, in SCHMITZ H. (Ed) Local Enterprises in the Global Economy: Issues of Governance and Upgrading, pp. 110-39. Edward Elgar, Cheltenham.

BECATTINI G. (1978) The development of light industry in Tuscany, Economic Notes 18, 107-23. BECATTINI G. (1979) Dal settore industriale al distretto industriale. Alcune considerazioni sull'unità di indagine dell'economia industriale, Rivista di economia e politica industriale 5, 7-21. 
BECATTINI G., BELLANDI M. and DE PROPRIS L. (2009) A Handbook of Industrial Districts. Edward Elgar, Cheltenham.

BORGA M. and ZEILE W. J. (2004) International fragmentation of production and the intrafirm trade of U.S. multinational companies, Working Paper No. 2004-02, U.S. Department of Commerce, Bureau of Economic Analysis.

BRESNAHAN T. F., BRYNJOLFSSON E. AND HITT, M. L. (2002) Information technology, workplace organisation, and the demand of skilled labor: firm-level evidence, Quarterly Journal of Economics 117, 339-76.

BRYNJOLFSSON E. and HITT M. L. (2000) Beyond computation: information technology, organization transformation and business performance, Journal of Economic Perspectives 14, 2348.

BUGAMELLI M. and PAGANO P. (2004) Barriers to investment in ICT, Applied Economics 36, 2275-86.

CAMUFFO A., FURLAN A. and GRANDINETTI R. (2007) Knowledge and capabilities in subcontractor's evolution: the Italian case, in SUSMAN G. I. (Ed) Small and Medium-sized Enterprises and the Global Economy, pp. 125-39. Edward Elgar, Cheltenham.

CANNARI L., MAGNANI M. and PELLEGRINI G. (2009) Quali politiche per il Sud? Il ruolo delle politiche nazionali e regionali nell'ultimo decennio, in BANCA D'ITALIA Mezzogiorno e politiche regionali, pp. 673-734, Roma.

CAPITALIA (1998) VII Indagine sulle imprese manifatturiere, Roma.

CAPITALIA (2001) VIII Indagine sulle imprese manifatturiere, Roma.

CONTINI B. and REVELLI R. (1989) The relationship between firm growth and labour demand, Small Business Economics 1, 309-14.

CORÒ G. and GRANDINETTI R. (1999) Strategie di delocalizzazione e processi evolutivi nei distretti italiani, L'Industria 4, 897-924. 
CORSINO M. and GABRIELE R. (2010) Product innovation and firm growth: evidence from the integrated circuit industry, Industrial Corporate and Change, doi:10.1093/icc/dtq050.

COSTA S. and FERRI G. (2007) The determinants and employment effects of international outsourcing: the case of Italy, Dipartimento di Scienze Economiche Series No. 16, Università di Bari.

DAVERI F. and JONA-LASINIO C. (2007) Off-shoring and productivity growth in the Italian manufacturing industries, LLEE Working Document No. 53.

DE ARCANGELIS G. and FERRI G. (2005) La specializzazione dei distretti: dai beni finali ai macchinari del made in Italy?, in OMICCIOLI M. AND SIGNORINI L. F. (Eds) Economie Locali e Competizione Globale, pp. 232-54. Il Mulino, Bologna.

DEL MONTE A. and PAPAGNI E. (2003) R\&D and the growth of firms: empirical analysis of a panel of Italian firms, Research Policy 32, 1003-14.

DOLAN C. and HUMPHREY J. (2000) Changing governance patterns in the trade in fresh vegetables between Africa and the United Kingdom, Environment and Planning A 36, 491-509.

DRIES L. and SWINNEN J. F. M. (2004) Foreign direct investment, vertical integration, and local suppliers: Evidence from the Polish dairy sector, World Development 32, 1525-44.

DUNNE P. and HUGHES A. (1994) Age, size, growth and survival: UK companies in the 1980's, Journal of Industrial Economics 42, 115-40.

DUNNING J. H. (1993) Multinational Enterprises and the Global Economy. Addison Wesley, Wokingham.

DUNNING J. H. (2001) The eclectic (OLI) paradigm of international production: Past, present and future, International Journal of the Economics of Business 8, 173-90.

EVANS D. S. (1987a) The relationship between firm, growth, size and age: estimates for 100 manufacturing industries, Journal of Industrial Economics 43, 115-40.

EVANS D. S. (1987b) Tests of alternative theories of firm growth, Journal of Political Economy, $95,657-74$. 
FALK M. (2002) Endogenous organizational change and the expected demand for different skill groups, Applied Economics Letters 9, 419-23.

FALZONI A. M. and TAJOLI L. (2008) Offshoring and the skill composition of employment in the Italian manufacturing industries, CESPRI Working Paper No. 219.

GEREFFI G. (1994) The organization of buyer-driven commodity chains: How US retailers shape overseas production networks, in GEREFFI G. and KORZENIEWICZ M. (Eds) Commodity Chains and Global Capitalism, pp. 95-122. Greenwood Press, Westport.

GEREFFI G. and KORZENIEWICZ M. (1994) Commodity Chains and Global Capitalism. Greenwood Press, Westport.

GEREFFI G. (1999) International trade and industrial upgrading in the apparel commodity chain, Journal of International Economics 48, 37-70.

GEREFFI G., HUMPHREY J. and STURGEON T. (2005) The governance of global value chains, Review of International Political Economy 12, 78-104.

GEROSKI P. A. (1998) An applied econometrician's view of large company performance, Review of Industrial Organization 13, 271-93.

GEROSKI P. A., MACHIN S. and WALTERS C. F. (1997) Corporate growth and profitability, Journal of Industrial Economics 46, 171-89.

GIANNOLA A. and SCALERA D. (1998) Il Mezzogiorno alla vigilia dell'Unione Monetaria: aspetti del dualismo Nord-Sud e prospettive dell'integrazione europea, Rivista Internazionale di Scienze Sociali 106, 299-326.

GIULIANI E., PIETROBELLI C., and RABELLOTTI R. (2005) Upgrading in global value chains: Lessons from Latin American clusters, World Development 33, 549-73.

GIUNTA A. (2010) L'incoerenza attuativa della Nuova politica regionale, QA - Rivista dell'Associazione Rossi Doria 2, 159-68.

GIUNTA A. and SCALERA D. (2007) L'impresa subfornitrice: redditività, produttività e divari territoriali, Economia e Politica Industriale 34, 123-46. 
GÖRG H., HANLEY A. and STROBL E. (2008) Productivity effects of international outsourcing: evidence from plant-level data, Canadian Journal of Economics 41, 670-88.

GUERRIERI P. and IAMMARINO S. (2001) Vulnerable regions in Europe: The case of Italian Mezzogiorno, Paper presented at the $41^{\text {st }}$ ERSA Congress, Zagreb.

GROSSMAN, G. M. and ROSSI-HANSBERG E. (2006) The rise of offshoring: it's not wine for cloth anymore, in FEDERAL RESERVE BANK OF KANSAS CITY The New Economic Geography: Effects and Policy Implications, Jackson Hole, pp. 59-102.

HANSON G. H., MATALONI R. J. JR. and SLAUGHTER M. J. (2003) Vertical production networks in multinational firms, NBER Working Paper W9723.

HARHOFF D., KONRAD S. and WOYWODE M. (1998) Legal form, growth and exit of West German firms. Empirical results for manufacturing, construction, trade and service industries, Journal of Industrial Economics 46, 453-88.

HART P. (2000) Theories of firms' growth and the generation of jobs, Review of Industrial Organization 17, 229-48.

HAVIK K. and MC MORROW K. (2006) Global trade integration and outsourcing: How well is the EU coping with the new challenges?, European Commission Directorate-General for Economic and Financial Affairs Economic Papers 259.

HEGGER H. and KREICKEMEIER U. (2008) International fragmentation: Boon or bane for domestic employment?, European Economic Review 52, 116-32.

HENDERSON J., DICKEN P., HESS M., COE N. and YEUNG H. (2002) Global production networks and the analysis of economic development, Review of International Political Economy 9, 436-64.

HUMPHREY J. and SCHMITZ H. (2002) How does insertion in global value chains affect upgrading in industrial clusters?, Regional Studies 36, 1017-27.

HUMPHREY J. and MEMEDOVIC O. (2003) The global automotive industry value chain: What prospects for upgrading by developing countries, UNIDO Sectoral Studies Series, Vienna. 
HUR J. J., SEO H. J. and LEE Y. (2005) Information and communication technology diffusion and skill upgrading in Korean industries, Economics of Innovation and New Technology 14, 553-71.

IACOVONE L and JAVORCIK B. (2010) Multi-product exporters: Product churning, uncertainty and export discoveries, Economic Journal 120, 481-99.

IETTO-GILLIES G. (2002) Hymer, the nation-state and the determinants of multinational corporations' activities, Contributions to Political Economy 21, 43-54.

INNOCENTI A. (2003) Production outsourcing in Italian manufacturing industry, in DI MATTEO M. and PIACENTINI P. (Eds) The Italian Economy at the Dawn of the $21^{\text {st }}$ Century, pp. 212-32. Ashgate, Aldershot.

JONES R. W. and KIERZKOWSKI H. (1990) The role of services in production and international trade: a theoretical framework, in JONES R. W. and KRUEGER A. O. (Eds) The Political Economy of International Trade. Essays in Honor of Robert E. Baldwin, pp. 31-48. Basil Blackwell, Cambridge.

JOVANOVIC B. (1982) Selection and the industry evolution, Econometrica 50, 649-70.

KAPLINSKY R. (2000) Spreading the gains from globalisation: What can be learned from Value Chain Analysis?, Institute for Development Studies, Sussex University, Brighton.

KIMURA F. (2002) Subcontracting and the performance of small and medium firms in Japan, Small Business Economics 18, 163-75.

KOENIG P., MAYNERIS F. and PONCET S. (2010) Local exports spillovers in France, European Economic Review 54, 622-41.

KOHLER W. (2009) Offshoring: Why do stories differ?, in G. TONDL (ed) The EU and Emerging Markets, pp. 25-49. Springer Verlag, Wien.

LOOF H. and HESHMATT A. (2006) On the relationship between innovation and performance: a sensitivity analysis, Economics of Innovation and New Technologies 15, 317-44.

MACPHERSON M. A. (1996) Growth of micro and small enterprises in Southern Africa, Journal of Development Economics 48, 253-77. 
LUCCHETTI R. and STERLACCHINI A. (2004) The adoption of ICT among SMEs: evidence from an Italian survey, Small Business Economics 23, 151-68.

MANSFIELD E. (1962) Entry, Gibrat's law, innovation, and the growth of firms, American Economic Review 52, 1023-51.

MARIN D. (2006) A new international division of labor in Europe: Outsourcing and offshoring to Eastern Europe, Journal of the European Economic Association 4, 612-22.

MAZZOLA F. and BRUNI S. (2000) The role of linkages in firm performance: evidence from Southern Italy, Journal of Economic Behaviour and Organization 43, 199-221.

MCLAREN J. (2000) Globalization and vertical structure, American Economic Review 90, 123954.

MENGHINELLO S. (2004) Local engines of global trade: the case of Italian industrial districts, in CAINELLI G. and ZOBOLI R. (Eds) The Evolution of Industrial Districts, pp. 319-35. PhysicaVerlag, New York.

MILGROM P. and ROBERTS J. (1990) The economics of modern manufacturing: technology, strategy and organization, American Economic Review 80, 511-28.

NORDÅS H. K. (2004) Location of engineering and designer services in the space economy, in DE GROOT H. L. F., NIJKAMP P. and STOUGH R. (Eds) Rising Entrepreneurship in a Shrinking World: A Spatial Perspective, pp. 271-91. Edward Elgar, Cheltenham.

NORDÅS H. K. (2005) International production sharing: a case for a coherent policy framework, Discussion Paper No. 11, World Trade Organization, Geneva.

OECD (2007a) Offshoring and Employment. Trends and Impacts. Paris.

OECD, (2007b) Moving Up the Value Chain: Staying Competitive in the Global Economy. Paris.

OLIVEIRA B. and FORTUNATO A. (2006) Testing Gibrat's law: Empirical evidence from a panel of Portuguese manufacturing firms, International Journal of the Economics of Business 13, 65-81.

OLSEN K. B. (2006) Productivity impacts of offshoring and outsourcing: A review, STI Working Paper No. 1, OECD, Paris. 
RAZZOLINI T. and VANNONI D. (2009) Strategie di export passivo, produzione su commessa e performance, L'Industria 3, 437-66.

ROSSI N. (2005) Mediterraneo del Nord. Laterza, Bari.

ROSSI S. (2006) La Regina e il Cavallo. Laterza, Bari.

SACCHETTI S. and SUGDEN R. (2003) The governance of networks and economic power: The nature and impact of subcontracting relationships, Journal of Economic Surveys 17, 669-91.

SALIOLA F. and ZANFEI A. (2009) Multinational firms, global value chains and the organization of knowledge transfer, Research Policy 38, 369-81.

SCALERA D. and ZAZZARO A. (2010) L'economia del Mezzogiorno: nuova politica regionale, crisi globale e federalismo fiscale, in GUERRA M. C. and ZANARDI A. (Eds) La Finanza Pubblica Italiana. Rapporto 2010, pp. 375-410. Il Mulino, Bologna.

SFORZI F. (2002) The industrial district and the 'new' Italian economic geography, European Planning Studies 10, 439-47.

STOCK J.H. and YOGO M. (2005) Testing for weak instruments in linear IV regression, in ANDREWS D. W. K. and STOCK J. H. (Eds) Identification and Inference for Econometric Models: Essays in Honor of Thomas Rothenberg, 80-108. Cambridge University Press, Cambridge. STURGEON T., VAN BIESEBROECK J. and GEREFFI G. (2008) Value chains, networks and clusters: reframing the global automotive industry, Journal of Economic Geography 8, 297-321.

SUTTON J. (1997) Gibrat's legacy, Journal of Economic Literature 35, 40-59.

TATTARA G., CORÒ G. and VOLPE M. (2006) La Delocalizzazione Internazionale come Strategia Competitiva. Carocci, Roma.

TRENTO S. and WARGLIEN M. (2003) Tecnologie digitali e cambiamento organizzativo, in ROSSI S. (Ed) La Nuova Economia, pp. 151-76. Il Mulino, Bologna.

UNIONCAMERE (2006) Rapporto Unioncamere. Roma.

VARIYAM J. N. and KRAYBILL D.S. (1992) Empirical evidence on determinants of firm growth, Economics Letters 38, 31-6. 
YASUDA T. (2005) Firm growth, size, age and behavior in Japanese manufacturing, Small Business Economics 24, 1-15. 
Table 1 - Employees

Panel A - Size distribution (number of observations)

\begin{tabular}{|l|c|c|c|c|c|}
\hline Employees & $11-50$ & $51-100$ & $101-250$ & $251-500$ & Over 500 \\
\hline Centre-North & 5588 & 991 & 621 & 425 & 306 \\
\hline Mezzogiorno & 880 & 180 & 115 & 35 & 22 \\
\hline NOSUB & 2524 & 534 & 368 & 235 & 186 \\
\hline LOSUB & 625 & 114 & 91 & 51 & 43 \\
\hline HISUB & 621 & 94 & 66 & 36 & 19 \\
\hline ONSUB & 2666 & 425 & 206 & 119 & 70 \\
\hline
\end{tabular}

Panel B - Average yearly growth rates. Mean and median (in parentheses) values

\begin{tabular}{|l|c|c|c|c|c|}
\hline & NOSUB & LOSUB & HISUB & ONSUB & Overall \\
\hline \multirow{2}{*}{$11-50$ employees } & 19.14 & 23.98 & 9.80 & 9.40 & 14.67 \\
& $(9.09)$ & $(11.11)$ & $(5.19)$ & $(2.27)$ & $(7.98)$ \\
\hline \multirow{2}{*}{$51-100$ employees } & 17.78 & 32.30 & 11.11 & 9.41 & 15.61 \\
& $(8.62)$ & $(23.43)$ & $(10.42)$ & $(7.27)$ & $(8.76)$ \\
\hline \multirow{2}{*}{$101-250$ employees } & 17.24 & 28.17 & 9.17 & 9.49 & 15.69 \\
& $(12.22)$ & $(20.00)$ & $(4.94)$ & $(4.73)$ & $(9.93)$ \\
\hline \multirow{2}{*}{$251-500$ employees } & 13.32 & 13.83 & 15.01 & 8.76 & 12.29 \\
& $(10.30)$ & $(9.17)$ & $(4.38)$ & $(3.23)$ & $(6.71)$ \\
\hline \multirow{2}{*}{ Over 500 employees } & 19.74 & 19.53 & 14.87 & 9.22 & 17.10 \\
& $(16.65)$ & $(23.13)$ & $(8.68)$ & $(0.83)$ & $(10.60)$ \\
\hline \multirow{2}{*}{ Centre-North } & 18.80 & 25.82 & 10.30 & 9.55 & 14.97 \\
& $(9.61)$ & $(18.14)$ & $(7.56)$ & $(2.52)$ & $(9.19)$ \\
\hline \multirow{2}{*}{ Mezzogiorno } & 17.73 & 13.81 & 8.87 & 8.45 & 12.04 \\
& $(14.19)$ & $(5.88)$ & $(3.51)$ & $(1.61)$ & $(6.14)$ \\
\hline \multirow{2}{*}{ Overall } & 18.44 & 24.65 & 10.24 & 9.38 & 14.84 \\
& $(9.72)$ & $(13.26)$ & $(5.63)$ & $(2.40)$ & $(7.84)$ \\
\hline
\end{tabular}




\begin{tabular}{|c|c|c|c|c|c|}
\hline \multicolumn{6}{|l|}{ Table 2 - Real sales } \\
\hline \multicolumn{6}{|c|}{ Panel A - Size distribution (number of observations) } \\
\hline $\begin{array}{l}\text { Billions Liras } \\
\text { (prices of year 2000) }\end{array}$ & Up to 10 & 10 to 50 & 50 to 200 & 200 to 500 & Over 500 \\
\hline Centre-North & 4400 & 2473 & 743 & 198 & 87 \\
\hline Mezzogiorno & 766 & 373 & 68 & 14 & 12 \\
\hline NOSUB & 1911 & 1302 & 450 & 122 & 56 \\
\hline LOSUB & 490 & 310 & 82 & 29 & 12 \\
\hline HISUB & 491 & 261 & 58 & 16 & 6 \\
\hline ONSUB & 2251 & 959 & 202 & 36 & 22 \\
\hline \multicolumn{6}{|c|}{ Panel B - Average yearly growth rates. Mean and median (in parentheses) values } \\
\hline & NOSUB & LOSUB & HISUB & ONSUB & Overall \\
\hline 11-50 employees & $\begin{array}{c}4.82 \\
(3.04)\end{array}$ & $\begin{array}{c}4.36 \\
(2.90)\end{array}$ & $\begin{array}{c}7.86 \\
(5.10)\end{array}$ & $\begin{array}{c}5.91 \\
(3.05)\end{array}$ & $\begin{array}{c}5.52 \\
(3.04)\end{array}$ \\
\hline 51-100 employees & $\begin{array}{l}-1.36 \\
(0.60)\end{array}$ & $\begin{array}{c}1.83 \\
(1.16)\end{array}$ & $\begin{array}{c}2.38 \\
(1.38)\end{array}$ & $\begin{array}{c}6.13 \\
(3.12)\end{array}$ & $\begin{array}{c}1.98 \\
(1.45)\end{array}$ \\
\hline 101-250 employees & $\begin{array}{c}4.92 \\
(3.99)\end{array}$ & $\begin{array}{c}5.54 \\
(3.86) \\
\end{array}$ & $\begin{array}{c}7.23 \\
(5.02) \\
\end{array}$ & $\begin{array}{c}5.80 \\
(3.75) \\
\end{array}$ & $\begin{array}{c}5.45 \\
(3.80)\end{array}$ \\
\hline 251-500 employees & $\begin{array}{l}3.66 \\
(3.14)\end{array}$ & $\begin{array}{c}4.57 \\
(3.03)\end{array}$ & $\begin{array}{c}6.83 \\
(4.44)\end{array}$ & $\begin{array}{c}5.42 \\
(3.88)\end{array}$ & $\begin{array}{c}4.50 \\
(3.21)\end{array}$ \\
\hline >500 employees & $\begin{array}{c}5.06 \\
(4.00) \\
\end{array}$ & $\begin{array}{c}9.19 \\
(6.41) \\
\end{array}$ & $\begin{array}{c}6.53 \\
(0.30) \\
\end{array}$ & $\begin{array}{c}5.32 \\
(3.83) \\
\end{array}$ & $\begin{array}{c}5.76 \\
(3.83) \\
\end{array}$ \\
\hline Centre-North & $\begin{array}{c}3.77 \\
(2.71)\end{array}$ & $\begin{array}{c}4.28 \\
(2.30)\end{array}$ & $\begin{array}{c}7.23 \\
(4.14)\end{array}$ & $\begin{array}{c}5.86 \\
(3.40)\end{array}$ & $\begin{array}{c}5.50 \\
(3.03)\end{array}$ \\
\hline Mezzogiorno & $\begin{array}{c}7.24 \\
(3.29) \\
\end{array}$ & $\begin{array}{c}6.53 \\
(2.70) \\
\end{array}$ & $\begin{array}{c}0.15 \\
(1.08)\end{array}$ & $\begin{array}{c}4.02 \\
(0.90) \\
\end{array}$ & $\begin{array}{c}5.22 \\
(1.76)\end{array}$ \\
\hline Overall & $\begin{array}{c}3.91 \\
(2.87)\end{array}$ & $\begin{array}{l}4.40 \\
(2.54)\end{array}$ & $\begin{array}{c}7.12 \\
(4.53)\end{array}$ & $\begin{array}{c}5.90 \\
(3.20)\end{array}$ & $\begin{array}{c}5.02 \\
(3.01)\end{array}$ \\
\hline
\end{tabular}


Table 3 - ANOVA tests of mean equality ( $\mathrm{t}$ and $\mathrm{F}$ values)

Panel A - Growth of employees

\begin{tabular}{|c|c|c|c|c|}
\hline & NOSUB & LOSUB & HISUB & ONSUB \\
\hline NOSUB & - & & & \\
\hline LOSUB & $\begin{array}{c}7.216 * * * \\
52.069 * * *\end{array}$ & - & & \\
\hline HISUB & $\begin{array}{c}16.256^{* * *} \\
264.249 * * *\end{array}$ & $\begin{array}{c}8.380 * * * \\
70.224 * * *\end{array}$ & - & \\
\hline ONSUB & $\begin{array}{l}29.075 * * * \\
845.331 * * *\end{array}$ & $\begin{array}{l}11.933 * * * \\
142.387 * * *\end{array}$ & $\begin{array}{l}0.174 \\
0.030\end{array}$ & - \\
\hline
\end{tabular}

Test on mean equality over all groups: $\mathrm{F}=318.641$ ***

Panel B - Growth of real sales

\begin{tabular}{|c|c|c|c|c|}
\hline & NOSUB & LOSUB & HISUB & ONSUB \\
\hline NOSUB & - & & & \\
\hline LOSUB & $\begin{array}{l}0.086 \\
0.007\end{array}$ & & & \\
\hline HISUB & $\begin{array}{c}3.873 * * * * \\
14.997 * * *\end{array}$ & $\begin{array}{l}2.989 * * * \\
8.936 * * *\end{array}$ & - & \\
\hline ONSUB & $\begin{array}{c}5.109 * * * \\
26.105 * * *\end{array}$ & $\begin{array}{l}3.059 * * * \\
9.359 * * *\end{array}$ & $\begin{array}{c}3.537 * * * \\
12.289 * * *\end{array}$ & - \\
\hline
\end{tabular}

Test on mean equality over all groups: $\mathrm{F}=11.709 * * *$ 


\begin{tabular}{|c|c|c|c|c|c|c|}
\hline \multicolumn{7}{|c|}{ Table 4 - Descriptive statistics } \\
\hline & Description & Obs & Mean & Max & Min & SD \\
\hline EMP & Number of employees & 9163 & 103.85 & 12630 & 11 & 369.18 \\
\hline AGE & Age of firm (in years) & 9115 & 23.57 & 182 & 0 & 18.03 \\
\hline AVK & Ratio added value / invested capital & 7713 & 0.04 & 2.58 & -0.18 & 0.06 \\
\hline AVL & Ratio added value / number of employed* & 7721 & 24.95 & 550.88 & -35.62 & 29.90 \\
\hline EXP & Dummy. Takes value 1 if the firm exports & 9134 & 0.69 & 1 & 0 & 0.46 \\
\hline SAL & Real value of sales** & 9134 & 41.30 & 8645.71 & 0 & 221.3 \\
\hline HUM & $\begin{array}{l}\text { Share of workers with a with a secondary } \\
\text { school degree }\end{array}$ & 8149 & 0.40 & 1 & 0 & 0.26 \\
\hline ICT & $\begin{array}{l}\text { Dummy. Takes value } 1 \text { if the firm makes } \\
\text { ICT investments }\end{array}$ & 8501 & 0.78 & 1 & 0 & 0.41 \\
\hline INP & $\begin{array}{l}\text { Dummy. Takes value } 1 \text { if the firm makes } \\
\text { product innovation }\end{array}$ & 9174 & 0.19 & 1 & 0 & 0.40 \\
\hline ROI & Value of ROI & 7721 & 0.20 & 5.52 & -4.58 & 0.71 \\
\hline SUB & Subcontracting intensity & 9107 & 0.48 & 1 & 0 & 0.47 \\
\hline SOU & $\begin{array}{l}\text { Dummy. Takes value } 1 \text { if the firm is } \\
\text { localized in a Southern region }\end{array}$ & 9177 & 0.13 & 1 & 0 & 0.34 \\
\hline $\begin{array}{l}\text { The nu } \\
\text { to the } \\
\text { year } 20\end{array}$ & $\begin{array}{l}\text { of observations for each estimation chan } \\
\text { nnaire. * values expressed in million lir }\end{array}$ & due $t$ & $\begin{array}{l}\text { dif } \\
\text { in } 1\end{array}$ & num lira & $\begin{array}{l}\text { f va } \\
\text { lues }\end{array}$ & $\begin{array}{l}\text { swers } \\
\text { ces of }\end{array}$ \\
\hline
\end{tabular}


Table 5 - The determinants of growth rates (real sales)

\begin{tabular}{|c|c|c|c|c|c|c|}
\hline & \multicolumn{2}{|c|}{ (1) } & \multicolumn{2}{|c|}{ (2) } & \multicolumn{2}{|c|}{ (3) } \\
\hline & OLS & GIV & OLS & GIV & OLS & GIV \\
\hline Log SAL & $\begin{array}{c}-0.0057 * * \\
(0.0020)\end{array}$ & $\begin{array}{c}-0.0205^{* *} \\
(0.0078)\end{array}$ & $\begin{array}{c}-0.0057 * * \\
(0.0020)\end{array}$ & $\begin{array}{c}-0.0408 * * * \\
(0.0131)\end{array}$ & $\begin{array}{c}-0.3420 * * \\
(0.1670)\end{array}$ & $\begin{array}{c}-0.0267 * * * \\
(0.0049)\end{array}$ \\
\hline$\Delta \mathrm{SAL}_{\mathrm{t}-1}$ & $\begin{array}{l}3.92 \mathrm{E}-06 \\
(2.86 \mathrm{E}-06)\end{array}$ & $\begin{array}{l}4.61 \mathrm{E}-06 \\
(3.12 \mathrm{E}-06)\end{array}$ & $\begin{array}{l}3.92 \mathrm{E}-06 \\
(2.86 \mathrm{E}-06)\end{array}$ & $\begin{array}{l}4.85 \mathrm{E}-06 \\
(12.9 \mathrm{E}-06)\end{array}$ & $\begin{array}{c}-5.86 \mathrm{E}-05 \\
(5.01 \mathrm{E}-05)\end{array}$ & $\begin{array}{l}8.08 \mathrm{E}-06 \\
(9.01 \mathrm{E}-06)\end{array}$ \\
\hline $\log A G E$ & $\begin{array}{c}-0.0438 * * * \\
(0.0087) \\
\end{array}$ & $\begin{array}{c}-0.0474 * * * \\
(0.0107) \\
\end{array}$ & $\begin{array}{c}-0.0438 * * * \\
(0.0087) \\
\end{array}$ & $\begin{array}{l}-0.0113 \\
(0.0513) \\
\end{array}$ & $\begin{array}{c}-0.0455^{* *} \\
(0.0177) \\
\end{array}$ & $\begin{array}{c}-0.0377 * * * \\
(0.0074) \\
\end{array}$ \\
\hline SOU & $\begin{array}{l}0.0148 \\
(0.0177)\end{array}$ & $\begin{array}{l}0.0075 \\
(0.0237)\end{array}$ & $\begin{array}{l}0.0148 \\
(0.0177)\end{array}$ & $\begin{array}{c}-0.0252 * \\
(0.0136)\end{array}$ & $\begin{array}{c}-0.09010 \\
(0.5230)\end{array}$ & $\begin{array}{l}0.1215 \\
(0.4209)\end{array}$ \\
\hline SUB & $\begin{array}{l}0.0026 \\
(0.0104)\end{array}$ & $\begin{array}{l}0.0098 \\
(0.0123)\end{array}$ & $\begin{array}{l}0.0019 \\
(0.0121)\end{array}$ & $\begin{array}{l}0.0017 \\
(0.0208)\end{array}$ & $\begin{array}{c}3.6336 * * \\
(1.5141)\end{array}$ & $\begin{array}{c}2.6492 * * * \\
(0.8710)\end{array}$ \\
\hline SUB $^{2}$ & - & & - & - & $\begin{array}{c}-3.5408 * * \\
(1.4119)\end{array}$ & $\begin{array}{c}-2.5768 * * * \\
(0.8484)\end{array}$ \\
\hline SXS & - & & - & - & $\begin{array}{c}-4.6440 * * \\
(2.2994)\end{array}$ & $\begin{array}{c}-2.9665 * * * \\
(0.8841)\end{array}$ \\
\hline $\mathrm{SXS}^{2}$ & - & & - & - & $\begin{array}{c}4.0087 * * \\
(1.7570)\end{array}$ & $\begin{array}{c}2.7327 * * * \\
(0.8671)\end{array}$ \\
\hline AVK & $\begin{array}{l}-4.88 \mathrm{E}-05 \\
(10.4 \mathrm{E}-05)\end{array}$ & $\begin{array}{l}-3.18 \mathrm{E}-04 \\
(3.30 \mathrm{E}-04)\end{array}$ & $\begin{array}{l}-4.90 \mathrm{E}-05 \\
(10.4 \mathrm{E}-05)\end{array}$ & $\begin{array}{l}-2.25 \mathrm{E}-04 \\
(2.32 \mathrm{E}-04)\end{array}$ & $\begin{array}{c}0.0013 * \\
(6.81 \mathrm{E}-04)\end{array}$ & $\begin{array}{c}3.66 \mathrm{E}-04 * * \\
(1.78 \mathrm{E}-04)\end{array}$ \\
\hline ICT & $\begin{array}{c}0.0421 * * * \\
(0.0101)\end{array}$ & $\begin{array}{c}0.0494 * * * \\
(0.0157)\end{array}$ & $\begin{array}{c}0.0421 * * * \\
(0.0101)\end{array}$ & $\begin{array}{c}0.0337 * * \\
(0.0169)\end{array}$ & $\begin{array}{c}0.2161 * * \\
(0.0099)\end{array}$ & $\begin{array}{c}0.0291 * \\
(0.0151)\end{array}$ \\
\hline INP & $\begin{array}{c}-3.66 \mathrm{E}-04 \\
(0.0108)\end{array}$ & $\begin{array}{c}-0.0078 \\
(0.0136)\end{array}$ & $\begin{array}{c}-0.0018 \\
(0.0168)\end{array}$ & $\begin{array}{l}-0.0688 \\
(0.1078)\end{array}$ & $\begin{array}{l}0.1451 \\
(0.1108)\end{array}$ & $\begin{array}{l}-0.0076 \\
(0.0135)\end{array}$ \\
\hline IXS & - & - & $\begin{array}{c}0.0378 * * \\
(0.0190)\end{array}$ & $\begin{array}{c}0.1970 * * \\
(0.0866)\end{array}$ & - & - \\
\hline Constant & $\begin{array}{c}0.2455 * * * \\
(0.0517) \\
\end{array}$ & $\begin{array}{c}0.0205 * * * \\
(0.0078) \\
\end{array}$ & $\begin{array}{c}0.2458 * * * \\
(0.0517)\end{array}$ & $\begin{array}{c}0.4582 * * \\
(0.2297) \\
\end{array}$ & $\begin{array}{c}2.8972 * * \\
(1.4201)\end{array}$ & $\begin{array}{l}0.1033 \\
(0.0683) \\
\end{array}$ \\
\hline Observations & 7047 & 6919 & 7047 & 6919 & 7047 & 6917 \\
\hline $\mathrm{R}^{2}$ & 0.0964 & - & 0.0965 & - & 0.2521 & - \\
\hline $\begin{array}{c}\text { Marginal effect } \\
\text { CN }\end{array}$ & - & - & - & - & 0.3052 & 0.2248 \\
\hline $\begin{array}{c}\text { Marginal effect } \\
\text { SOU }\end{array}$ & - & - & - & & -0.5706 & -0.1764 \\
\hline $\begin{array}{c}\text { Turning point } \\
\text { CN }\end{array}$ & - & - & - & - & 0.5131 & 0.5145 \\
\hline $\begin{array}{l}\text { Turning point } \\
\text { SOU }\end{array}$ & - & - & - & - & 1.0797 & 1.0678 \\
\hline $\begin{array}{c}\text { Sargan test } \\
\text { (p value) }\end{array}$ & - & 0.7703 & - & 0.5131 & - & 0.4692 \\
\hline
\end{tabular}


Table 6 - The determinants of growth rates (employees)

\begin{tabular}{|c|c|c|c|c|c|c|}
\hline & \multicolumn{2}{|c|}{ (1) } & \multicolumn{2}{|c|}{ (2) } & \multicolumn{2}{|c|}{ (3) } \\
\hline & OLS & GIV & OLS & GIV & OLS & GIV \\
\hline Log EMP & $\begin{array}{c}-0.1499 * * * \\
(0.0240)\end{array}$ & $\begin{array}{c}-0.1606^{* * * *} \\
(0.0250)\end{array}$ & $\begin{array}{c}-0.1501 * * * \\
(0.0240)\end{array}$ & $\begin{array}{c}-0.1974 * * * \\
(0.0546)\end{array}$ & $\begin{array}{c}-0.1508 * * * \\
(0.0240)\end{array}$ & $\begin{array}{c}-0.1450 * * * \\
(0.0271)\end{array}$ \\
\hline$\Delta \mathrm{EMP}_{\mathrm{t}-1}$ & $\begin{array}{c}-0.8742 * * * \\
(0.3197)\end{array}$ & $\begin{array}{c}-0.8013 * * \\
(0.3173)\end{array}$ & $\begin{array}{c}-0.8744 * * * \\
(0.3199)\end{array}$ & $\begin{array}{c}-1.1202 * * * \\
(0.1496)\end{array}$ & $\begin{array}{c}-0.8738 * * * \\
(0.3202)\end{array}$ & $\begin{array}{c}-0.9144 * * * \\
(0.3482)\end{array}$ \\
\hline Log AGE & $\begin{array}{r}-0.0177 \\
(0.0137)\end{array}$ & $\begin{array}{c}-0.0295^{*} \\
(0.0176)\end{array}$ & $\begin{array}{l}-0.0179 \\
(0.0137)\end{array}$ & $\begin{array}{l}-0.0400 \\
(0.0612)\end{array}$ & $\begin{array}{c}-0.0162 \\
(0.0138)\end{array}$ & $\begin{array}{l}-0.0148 \\
(0.0250)\end{array}$ \\
\hline SOU & $\begin{array}{l}0.0640 \\
(0.0490)\end{array}$ & $\begin{array}{l}0.0365 \\
(0.0659)\end{array}$ & $\begin{array}{l}0.0643 \\
(0.0492)\end{array}$ & $\begin{array}{l}0.0625 \\
(0.1115)\end{array}$ & $\begin{array}{l}0.0416 \\
(0.0480)\end{array}$ & $\begin{array}{l}0.0707 \\
(0.1579)\end{array}$ \\
\hline SUB & $\begin{array}{l}0.0228 \\
(0.0546)\end{array}$ & $\begin{array}{l}0.0404 \\
(0.0339)\end{array}$ & $\begin{array}{l}0.0226 \\
(0.0418)\end{array}$ & $\begin{array}{l}0.0390 \\
(0.1341)\end{array}$ & $\begin{array}{c}0.2018 * \\
(0.1133)\end{array}$ & $\begin{array}{c}16.4096^{* * * *} \\
(3.7725)\end{array}$ \\
\hline $\mathrm{SUB}^{2}$ & - & & - & - & $\begin{array}{c}-0.1935^{*} \\
(0.1054)\end{array}$ & $\begin{array}{c}-16.0162 * * * \\
(3.6694)\end{array}$ \\
\hline SXS & - & & - & - & $\begin{array}{c}-0.3429 * \\
(0.1943)\end{array}$ & $\begin{array}{c}-16.6609 * * * \\
(3.7292)\end{array}$ \\
\hline $\mathrm{SXS}^{2}$ & - & & - & - & $\begin{array}{c}0.2514 * \\
(0.1382)\end{array}$ & $\begin{array}{c}16.1412 * * * \\
(3.6551)\end{array}$ \\
\hline AVK & $\begin{array}{c}0.0043 * * * \\
(0.0009)\end{array}$ & $\begin{array}{c}0.0033 * * * \\
(0.0012)\end{array}$ & $\begin{array}{c}0.0043 * * * \\
(0.0009)\end{array}$ & $\begin{array}{c}0.0052 * * * \\
(0.0018)\end{array}$ & $\begin{array}{c}0.0043 * * * \\
(0.0009)\end{array}$ & $\begin{array}{c}0.0068 * * * \\
(0.0013)\end{array}$ \\
\hline ICT & $\begin{array}{c}0.1262 * * * \\
(0.0233)\end{array}$ & $\begin{array}{c}0.1477 * * * \\
(0.0254)\end{array}$ & $\begin{array}{c}0.1173 * * * \\
(0.0236)\end{array}$ & $\begin{array}{c}0.1731 * * \\
(0.0877)\end{array}$ & $\begin{array}{c}0.1239 * * * \\
(0.0227)\end{array}$ & $\begin{array}{l}0.0312 \\
(0.0463)\end{array}$ \\
\hline INP & $\begin{array}{c}0.0995 * * \\
(0.0399)\end{array}$ & $\begin{array}{c}0.0792 * \\
(0.0427)\end{array}$ & $\begin{array}{l}0.0558 \\
(0.0583)\end{array}$ & $\begin{array}{l}-0.1424 \\
(0.2508)\end{array}$ & $\begin{array}{c}0.0982 * * \\
(0.0400)\end{array}$ & $\begin{array}{l}0.0334 \\
(0.0494)\end{array}$ \\
\hline IXS & - & - & $\begin{array}{c}0.5302 * * * \\
(0.0675)\end{array}$ & $\begin{array}{c}0.4384 * \\
(0.2562) \\
\end{array}$ & - & - \\
\hline Constant & $\begin{array}{c}0.5439 * * * \\
(0.0807) \\
\end{array}$ & $\begin{array}{c}0.8394 * * * \\
(0.2774) \\
\end{array}$ & $\begin{array}{c}0.5517 * * * \\
(0.0779)\end{array}$ & $\begin{array}{l}0.6408 \\
(0.7507) \\
\end{array}$ & $\begin{array}{c}0.5446 * * * \\
(0.0794) \\
\end{array}$ & $\begin{array}{l}-0.2420 \\
(0.1928) \\
\end{array}$ \\
\hline Observations & 7015 & 6889 & 7015 & 6889 & 7015 & 6889 \\
\hline $\mathrm{R}^{2}$ & 0.1994 & - & 0.1995 & - & 0.1999 & - \\
\hline $\begin{array}{c}\text { Marginal effect } \\
\text { CN }\end{array}$ & - & - & - & & 0.0199 & 1.3544 \\
\hline $\begin{array}{c}\text { Marginal effect } \\
\text { SOU }\end{array}$ & - & - & - & & -0.0867 & -0.1372 \\
\hline $\begin{array}{c}\text { Turning point } \\
\text { CN }\end{array}$ & - & - & - & - & 0.5214 & 0.5123 \\
\hline $\begin{array}{l}\text { Turning point } \\
\text { SOU }\end{array}$ & - & - & - & - & 1.2185 & 1.0052 \\
\hline $\begin{array}{c}\text { Sargan test } \\
\text { (p value) }\end{array}$ & - & 0.8923 & - & 0.8964 & - & 0.8759 \\
\hline
\end{tabular}

